\title{
Assessment of Domestic Water Sources Safety: Application of the Micro Biological Survey Method and Microbiological Profile of the Contaminating Bacteria
}

\author{
Sali Ben Béchir Adogaye ${ }^{*}$, Mabvouna Biguioh Rodrigue1, Nkamedjie Pete Patrick Martial2, \\ Andrillene Laure Deutou Wondeu ${ }^{1,2}$, Sanou Sobze Martin'2,3, Jean Blaise Kemogne2, \\ Carla Montesano', Colizzi Vittorio', \\ ${ }^{1}$ Department of Biology, Faculty of Sciences, University of Rome “Tor Vergata”, Rome, Italy \\ ${ }^{2}$ Evangelical University of Cameroon, Mbouo-Bandjoun, Cameroon \\ ${ }^{3}$ Faculty of Medicine and Pharmaceutical Sciences, University of Dschang, Dschang, Cameroon \\ Email: `benbechir_sali@yahoo.fr, rodrigue.biguioh@yahoo.fr, patricknkamedjie@yahoo.com, andrillene.1@gmail.com, \\ martinsobze@hotmail.com, jean-blaise.kenmogne@uecam.org, montesan@uniroma2.it, colizzi@bio.uniroma2.it
}

How to cite this paper: Adogaye, S.B.B., Rodrigue, M.B., Martial, N.P.P., Wondeu, A.L.D., Martin, S.S., Kemogne, J.B., Montesano, C. and Vittorio, C. (2021) Assessment of Domestic Water Sources Safety: Application of the Micro Biological Survey Method and Microbiological Profile of the Contaminating Bacteria. Journal of Water Resource and Protection, 13, 350-361. https://doi.org/10.4236/jwarp.2021.135022

Received: January 19, 2021

Accepted: May 18, 2021

Published: May 21, 2021

Copyright $\odot 2021$ by author(s) and Scientific Research Publishing Inc. This work is licensed under the Creative Commons Attribution International License (CC BY 4.0).

http://creativecommons.org/licenses/by/4.0/ (c) (i) Open Access

\begin{abstract}
Water is essential for human life and it's expected to be clean and safe. In Cameroon, government efforts to improve access to drinking water are mitigated. Many households are suffering from chronic water shortages leading to the majority of people using doubtful water sources. This study was carried out in accordance with guidelines produced by the STARBIOS2-EU funded project on Responsible Research and Innovation and aimed to assess the microbiological quality of water samples collected from domestic water sources in 3 divisions of the West region of Cameroon. 22 water samples from well water, stream, water pump and river were aseptically collected. At each sampling point, $50 \mathrm{~mL}$ of sample was taken aseptically and immediately transported to the laboratory for analysis. The detection of Coliforms bacteria was done using Micro Biological Survey (MBS) method. $1 \mathrm{~mL}$ of each sample was inoculated in the Coliforms MBS (Coli MBS) vial initially rehydrated with 10 $\mathrm{mL}$ of sterile distilled water. The Coli MBS vials were closed, shaken for homogenization, and then incubated at $37^{\circ} \mathrm{C}$. From the initial red color of the Coli MBS vials, changes in color to yellow of the reaction vials were monitored at three different time intervals ( $12 \mathrm{~h}, 19 \mathrm{~h}$ and $24 \mathrm{~h}$ ), corresponding to three levels of bacterial concentration. All positives samples on MBS method were selected to determine the presence of $E$. coli Loop full broths of Coli MBS vials were taken; streaked into the eosin methylene blue (EMB) agar plate and incubated at $37^{\circ} \mathrm{C}$ for 24 hours. E. coli was confirmed by observing
\end{abstract}


green metallic sheen on EMB agar plate. The biochemical indole, methyl red, Voges-Proskauer and citrate (IMViC) test was performed to determine the complete microbiological profile of the water samples. Almost all the water samples were contaminated with Total Coliforms (TC). A high concentration of TC $\left(>10^{3} \mathrm{CFU} / \mathrm{mL}\right)$ was found in 8 samples $(36.4 \%)$, a medium concentration $\left(10<x<10^{3} \mathrm{CFU} / \mathrm{mL}\right)$ was observed in 10 samples $(45.5 \%)$ and 2 samples $(9.1 \%)$ were low concentrated $(1<x<10 \mathrm{CFU} / \mathrm{mL}) .8$ samples were positive for the presence of $E$. coli by observing the green metallic sheen on EMB agar plates. The IMViC test confirmed the presences of 5 bacteria species: $E n-$ terobacter spp., Klebsiella spp., E. coli spp., Salmonella spp. and Shigella spp. We recommend integrating sanitary assessment in the design and implementation of water supply projects. Regular water purification using proper methods and maintenances of the water point. Regular microbiological quality assessment of water intended for human consumption should be planned and carried out.

\section{Keywords}

Water Assessment, Micro Biological Survey Method, Biochemical IMViC Test, West Cameroon

\section{Introduction}

The supply of good quality domestic drinking water is often considered an important means of improving health [1]. The World Health Organization (WHO), in its recommendations for the quality of drinking water, has recommended placing more emphasis on the quality of water used for domestic tasks [2]. Globally, over 2 billion people still rely on unsafe water sources (stream, rivers, lakes, wells water, water pump); almost half of them are in sub-Saharan Africa (42\%) [3] [4]. In Cameroon, efforts to improve access to drinking water have been moderately successful in urban areas but mitigated in rural areas. The proportion of households using safe drinking water (from an improved source) was estimated at $71 \%$ in 2011 . This proportion is higher in urban areas (91\%) than in rural areas (50\%) [5]. Households are suffering from chronic water shortages in many localities [5]. Local authorities, non-governmental organization and local elites initiated to implement water wells, water pump, and improve existing water sources to increase the supply of safe water to people. Though improved water sources are considered to be "safe", their microbiological quality was not assessed prior to utilization highlighting the potential occurrence of waterborne diseases. The assessment of drinking water quality is an integral part of water management. Prompt and proper determination of microbiological quality of water can further aid in such initiatives and in taking appropriate action to ensure safety of water intended for human consumption.

Assessment of bacteria and other contaminants in water traditionally requires laboratory-conducted tests. Usually, microbiological quality of drinking water is 
assessed by monitoring hygiene indicator bacteria [6], especially, Escherichia coli (E. coli) and Enterococcus which are obligatory microbial parameters [7]. There are many sources of contamination of drinking water resulting from human activities [2] [3] [4]. Water microorganism contaminants are mostly bacteria of faecal origin (faecal indicator bacteria) [8]. Performing bacteriological tests on sampled water using traditional methods is time-consuming and requires qualified staff and high-level equipment. For the moment, only one laboratory, the Pasteur Centre of Cameroon can carry out quality bacteriological tests and local capacity for this does not exist.

There are several methods to determine the microbiological sanitary quality of drinking water. Detection and enumeration of faecal indicator bacteria is the basic and most widely microbiology method used [2]. The presence of coliforms and other pathogens in drinking water may be due to absence, ineffective or poor application of water treatment techniques [9] [10]. The coliforms are considered as the principal indicators of potability of drinking water. Their presence in water indicates faecal contamination which may account for water-borne diseases [2] [3]. Rapid detection of coliforms in water is therefore necessary which can simply be carried out by Micro Biological Survey method (MBS), a quantitative test to detect and enumerate Coliforms in water samples and thereby to determine easily the sanitary of water [11]. The MBS is designed to rapidly determine and at a lower cost whether drinking water faces any microbiological water quality problems that are of significant public health concern. Given that, the primary goal of water quality management from a public health perspective is to guarantee that individuals are not exposed to pathogenic microorganisms that are likely to cause disease, the MBS method could be an adapted technic for the routine microbiological quality check of water in low-limited resources settings. Along these lines, the present study attempted to assess the microbiological quality of water samples collected from domestic water sources in selected localities of the West region of Cameroon. We determine the quality of water samples as safe or not by observing the colour changes from red to yellow through MBS method which was applied as presumptive test. Then we used culture and biochemical tests to isolate bacteria in samples. The validation of this approach is part of the strategy that our institutions are developing to apply Responsible Research and Innovation in developing countries such as Cameroon [12].

\section{Methods}

\subsection{Study Location}

The study area comprised 3 of the 8 divisions of the West region of Cameroon (https://upload.wikimedia.org/wikipedia/commons/2/2a/West_Cameroon_divisi ons.png). These 3 divisions with approximately $60 \%$ of the West region population covered both urban and rural areas [13]. Inhabitants are mostly traders and practice intensive farming (coffee, potatoes, maize, beans, and vegetables) which have significant impact on the water quality. 


\subsection{Study Design and Period}

This was a cross-sectional study carried-out in November 2018. 22 water samples from water well, stream, water pump and river were aseptically collected. At sampling point, $50 \mathrm{~mL}$ of sample was taken in sterile plastic tubes; $1 \mathrm{~mL}$ of Sodium Thiosulfate solution $10 \%(0.25 \mathrm{~g} / 50 \mathrm{~mL})$ was added to the sample for chlorinated water sources and immediately placed in an ice box and then transported to the laboratory for microbiological quality analysis. The physicochemical parameters of water sources were measured in the field at the time of sampling using portables $\mathrm{pH}$ meters and thermometers.

\subsection{Presumptive Test: Application of MBS Method}

The quantitative detection of Coliforms in water samples was done using MBSHACCP \& water Easy test. This method is based on the visual observation of the color change in the suspension formed in the analysis vial used when the test sample is inoculated. The color change occurs when the water sample added in the vial contains Coliform bacteria. The results (concentration of bacteria) are expressed in Colony Forming Units $(\mathrm{CFU} / \mathrm{mL})$ for the analysis water samples. The test can both determine the presence of coliform bacteria and estimate the actual load of coliform in water sample.

\subsection{MBS Operating Procedures}

We used the MBS standard protocol for quantitative detection of Total Coliforms [14]. The Coliforms MBS (Coli MBS) vials were pre-rehydrated with 10 $\mathrm{mL}$ of sterile distilled water and shaken for about 30 seconds to dissolve the reagent contained in the vial. $1 \mathrm{~mL}$ of each water sample was taken from plastic bottles using a sterile Pasteur pipette and introduced in the Coli MBS vial. The vials were then closed and mixed for about 30 seconds for homogenization. Each sample analysis was performed twice, and the vials were placed in the thermostatic incubator at $37^{\circ} \mathrm{C}$. The color changes of the Coli MBS reaction vials were monitored using the chromatic scale provided with the tests, at three different time points (12 hours, 19 hours, and 24 hours), corresponding to three levels of contamination. The initial color of the Coli MBS vials is red; this turns to yellow in presence of Coliforms (Table 1). The main advantage of using MBS method is

Table 1. Correlation table for MBS Total Coliforms vials at $37^{\circ} \mathrm{C}$ between times required for vials color change (in hours) and bacterial concentration in the sample (in CFU/mL).

\begin{tabular}{ccccc}
\hline $\begin{array}{c}\text { Start } \\
\text { analysis }\end{array}$ & $\begin{array}{c}\text { Color } \\
\text { after } 12 \mathrm{~h}\end{array}$ & $\begin{array}{c}\text { Color } \\
\text { after } 19 \mathrm{~h}\end{array}$ & $\begin{array}{c}\text { Color } \\
\text { after } 24 \mathrm{~h}\end{array}$ & Bacterial concentration (CFU/mL) \\
\hline Red & Yellow & Yellow & Yellow & $>10^{3}=$ High \\
Red & Red & Yellow & Yellow & $10<x<10^{3}=$ Medium \\
Red & Red & Red & Yellow & $1<x<10=$ low \\
Red & Red & Red & Red & $<1=$ No contamination \\
\hline
\end{tabular}


the net savings of skills, costs and time. The time required for analysis including preparation and results acquisition are $2-5$ times lower in respect to the traditional methods. The analysis can be performed by anyone, anywhere without using other reagents or instruments and the cost is $2-4$ times lower than the traditional methods, which have to be performed by specialists in laboratories equipped with specific instruments.

\subsection{Identification of Coliform Bacteria}

The Coli MBS vials showing positive results by color change were selected to determine the presence of $E$. coli in the respective water samples (Figure 1). From positive vials, loop full samples were taken and streaked into the eosin methylene blue (EMB) agar plate and incubated at $37^{\circ} \mathrm{C}$ for 24 hours. E. coli was confirmed by observing green metallic sheen on EMB agar plate. Gram staining was done for the confirmation of $E$. coli isolates. This procedure helped to detect and differentiate $E$. coli from other Gram-negative bacteria. For species identification the biochemical indole, methyl red, Voges-Proskauer and citrate (IMViC) test was performed to determine the complete microbiological profile of the water samples [15] [16]. All the experiments were done three times and the tests were reproducible. One representative result was retained to be presented.

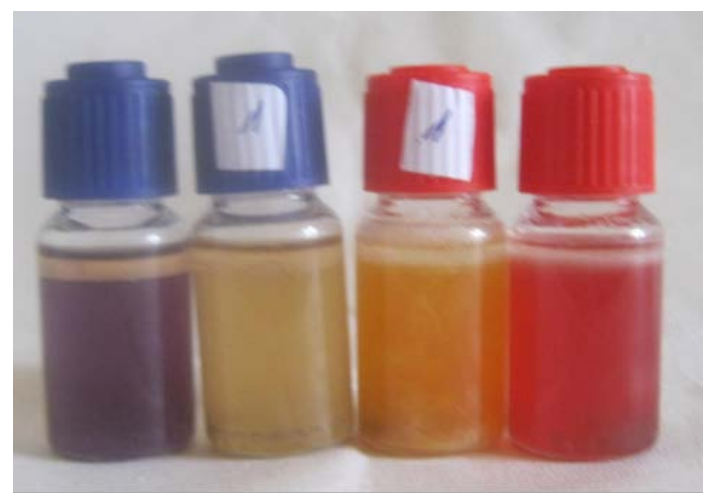

Figure 1. From left to right: Negative control vial for total viable count; positive total viable count vial; positive total Coliforms vial and negative control vial for total Coliforms.

\subsection{Ethical Approval}

This study is an application of the guidelines produced by the STARBIOS2-EU funded project on Responsible Research and Innovation [14]. No animal or human data or tissue were reported or used in this study, so ethical approval and consent were not required with reference to Order No. 079/A/MSP/DS of the Minister of Public Health of October 22, 1987 establishing and organizing an Ethics Committee on Research Involving Human Beings (article 2).

\section{Results}

Samples were in a total of 22 water points. Most of the samples were collected from wells (63.6\%) and streams (27.2\%). 


\subsection{Characteristics and Physicochemical Parameters}

The mean approximate depth of water sources was $8.03 \pm 1.1$ standard error (SE) meters; distance to nearest latrine $4.3 \pm 0.4 \mathrm{SE}$ and less than half were chlorinated (40.91\%). Regarding the physicochemical parameters, the mean $\mathrm{pH}$ of water samples was $6.5 \pm 0.1 \mathrm{SE}$, temperature $23.3^{\circ} \mathrm{C} \pm 0.1 \mathrm{SE}$. Acceptable turbidity $(1-5)$ in nephelometric turbidity unit (NTU) and clear appearance was noticed in $90.9 \%$ of samples (Table 2 ).

The comparison of some parameters with WHO drinking water quality criteria revealed that almost all water samples met the WHO acceptable range for turbidity (1 - $5 \mathrm{NTU}$ ) and physical appearance (colorless). The $\mathrm{pH}$ was found to be out of range (unacceptably low and high) in 14 (63.6\%) water samples. No source of water was found to be at acceptable distance (at least 15 meters) to the nearest latrine. Samples temperatures recorded at the sampling site were high and did not meet the WHO standard of $<15^{\circ} \mathrm{C}$ (Table 3).

Table 2. Characteristics and physicochemical quality parameters of water sources samples of West region, Cameroon.

\begin{tabular}{cccccc}
\hline & Frequency & Percent & Mean & SE & {$[95 \%$ CI $]$} \\
\hline Approximate depth in meter & - & - & 8.03 & \pm 1.1 & {$[5.7-10.3]$} \\
Distance to nearest latrine in meter & - & - & 4.3 & \pm 0.4 & {$[3.4-5.2]$} \\
Ph & - & - & 6.5 & \pm 0.1 & {$[6.2-6.8]$} \\
Temperature ${ }^{\circ} \mathrm{C}$ & - & - & 23.3 & \pm 0.1 & {$[22.9-23.6]$} \\
\hline Water chlorination & & & & & \\
No treated & 13 & 59.09 & - & - & {$[36.4-79.3]$} \\
Treated & 9 & 40.91 & - & - & {$[20.7-63.6]$} \\
\hline Water appearance & & & & & \\
Clear & 20 & 90.9 & - & - & {$[70.8-98.9]$} \\
Yellowish & 2 & 9.1 & - & - & {$[1.1-29.2]$} \\
\hline Turbidity (NTU) & & & & & \\
Acceptable (1 - 5) & 20 & 90.9 & - & - & {$[70.8-98.9]$} \\
Poor $(>5)$ & 2 & 9.1 & - & - & {$[1.1-29.2]$} \\
\hline
\end{tabular}

Table 3. Water sources compliance to WHO physicochemical quality standards of water samples in the West region of Cameroon.

\begin{tabular}{ccccc}
\hline \multirow{2}{*}{ Parameters } & \multicolumn{2}{c}{ Compliance } & \multicolumn{2}{c}{ Noncompliance } \\
\cline { 2 - 5 } & Freq. (\%) & {$[95 \% \mathrm{CI}]$} & Freq. (\%) & {$[95 \% \mathrm{CI}]$} \\
\hline Distance to nearest latrine (in meters) & 0 & - & $22(100)$ & {$[100-100]$} \\
$\mathrm{Ph}$ & $8(36.4)$ & {$[17.2-59.3]$} & $14(63.6)$ & {$[40.7-82.8]$} \\
Water appearance & $20(90.9)$ & {$[70.8-98.9]$} & $2(9.1)$ & {$[1.1-29.2]$} \\
Turbidity (NTU) & $20(90.9)$ & {$[70.8-98.9]$} & $2(9.1)$ & {$[1.1-29.2]$} \\
Temperature ${ }^{\circ} \mathrm{C}$ & 0 & - & $22(100)$ & {$[100-100]$} \\
\hline
\end{tabular}




\subsection{Microbiological Analysis Results: Detection and Identification of Coliforms Bacteria}

Concerning the presumptive test, results shown that almost all the water samples were contaminated with Total Coliforms (TC), except two wells where samples were potables [TC counts $<1 \mathrm{CFU} / 100 \mathrm{~mL}$ ]. A high concentration of TC $\left(>10^{3}\right.$ $\mathrm{CFU} / \mathrm{mL})$ was found in 8 samples (36.4\%), a medium concentration $(10<x<$ $10^{3} \mathrm{CFU} / \mathrm{mL}$ ) was observed in 10 samples (45.5\%) and 2 samples (9.1\%) were low concentration $(1<x<10 \mathrm{CFU} / \mathrm{mL})$. Among the water samples found positives in the MBS method, 8 of them were positive for the presence of $E$. coli by observing the green metallic sheen on EMB agar plates (Table 4). All positives samples on MBS methods (including positives sample on EMB agar) were passed on IMViC test to determine microbiological profile of the contaminating species water samples. 5 species of bacteria were identified: Enterobacter spp., Klebsiella spp., E. coli spp., Salmonella spp. and Shigella spp. (Table 5). Enterobacter spp. and $E$. coli spp. were the most contaminating bacteria found respectively in $50 \%$ and $40 \%$ of water samples. The other bacteria were found in $20 \%$ of water samples (Salmonella spp. Klebsiella spp.) and $10 \%$ of water samples were contaminated with Shigella spp. (Table 6).

Table 4. MBS method and EMB agar results of water samples in the West region of Cameroon.

\begin{tabular}{|c|c|c|c|c|}
\hline Sample & $\begin{array}{c}\text { Total coliform } \\
\text { concentration }(\mathrm{cfu} / \mathrm{mL})\end{array}$ & $\begin{array}{l}\text { Contamination } \\
\text { range }\end{array}$ & $\begin{array}{c}\text { Green } \\
\text { metallic sheen }\end{array}$ & Result \\
\hline Stream & $1<x<10$ & Low & - & Non-potable \\
\hline River & $>10^{3}$ & High & + & Non-potable \\
\hline Well water & $<1$ & No contamination & - & Potable \\
\hline Well water & $10<x<10^{3}$ & Medium & - & Non-potable \\
\hline Well water & $>10^{3}$ & High & + & Non-potable \\
\hline Stream & $1<x<10$ & Low & - & Non-potable \\
\hline Well water & $10<x<10^{3}$ & Medium & + & Non-potable \\
\hline Stream & $>10^{3}$ & High & - & Non-potable \\
\hline Well water & $10<x<10^{3}$ & Medium & + & Non-potable \\
\hline Water pump & $10<x<10^{3}$ & Medium & - & Non-potable \\
\hline Stream & $>10^{3}$ & High & - & Non-potable \\
\hline Well water & $<1$ & No contamination & - & Potable \\
\hline Well water & $>10^{3}$ & High & - & Non-potable \\
\hline Well water & $>10^{3}$ & High & + & Non-potable \\
\hline Well water & $10<x<10^{3}$ & Medium & - & Non-potable \\
\hline Well water & $10<x<10^{3}$ & Medium & - & Non-potable \\
\hline Well water & $>10^{3}$ & High & + & Non-potable \\
\hline Stream & $10<x<10^{3}$ & Medium & - & Non-potable \\
\hline Well water & $10<x<10^{3}$ & Medium & + & Non-potable \\
\hline Stream & $10<x<10^{3}$ & Medium & - & Non-potable \\
\hline Well water & $10<x<10^{3}$ & Medium & - & Non-potable \\
\hline Well water & $10<x<10^{3}$ & Medium & + & Non-potable \\
\hline
\end{tabular}


Table 5. IMViC results of positives samples on MBS method.

\begin{tabular}{ccccc}
\hline Bacteria species & MR test & VP test & Indole test & Citrate test \\
\hline Escherichia coli & + & + & - & - \\
Klebsiella spp. & - & - & + & + \\
Shigella spp. & - & + & - & - \\
Salmonella spp. & - & + & - & + \\
Enterobacter spp. & - & - & + & + \\
\hline
\end{tabular}

Note: MR: Methyl red, VP: Voges-Proskauer.

Table 6. Microbiological profile of water sample found positive on MBS method in the West region of Cameroon.

\begin{tabular}{|c|c|c|c|c|c|}
\hline Sample & $\begin{array}{c}\text { Enterobacter } \\
\text { spp. }\end{array}$ & $\begin{array}{l}\text { Klebsiella } \\
\text { spp. }\end{array}$ & $\begin{array}{l}\text { E. coli } \\
\text { spp. }\end{array}$ & $\begin{array}{l}\text { Salmonella } \\
\text { spp. }\end{array}$ & $\begin{array}{l}\text { Shigella } \\
\text { spp. }\end{array}$ \\
\hline Stream & - & + & - & - & - \\
\hline River & + & - & + & - & - \\
\hline Well Water & - & - & - & - & - \\
\hline Well Water & - & - & - & - & + \\
\hline Well Water & + & - & + & - & - \\
\hline Stream & - & - & - & + & - \\
\hline Well Water & + & - & + & - & - \\
\hline Stream & - & - & - & + & - \\
\hline Well Water & - & - & + & - & + \\
\hline Water Pump & + & - & - & - & - \\
\hline Stream & + & + & - & - & - \\
\hline Well Water & - & - & - & - & - \\
\hline Well Water & + & - & - & - & - \\
\hline Well Water & - & + & + & - & - \\
\hline Well Water & + & - & - & - & - \\
\hline Well Water & + & - & - & - & - \\
\hline Well Water & - & - & + & - & - \\
\hline Stream & - & - & - & + & - \\
\hline Well Water & - & + & + & - & - \\
\hline Stream & + & - & - & + & - \\
\hline Well Water & + & - & - & - & - \\
\hline Well Water & - & - & + & - & - \\
\hline
\end{tabular}

\section{Discussion}

The physiochemical parameters and the microbiological profile of collected water samples from river, streams, wells water and water pump were assessed. The results showed that average distance from the water sources to nearest latrine 
range from 3.9 to 4.7 meters and therefore, did not meet the WHO standard of a minimal (15 meters) between latrine and water source to avoid external contamination [2] [3]. The recorded mean \pm SE temperature of the water samples was $23.3^{\circ} \mathrm{C} \pm 0.1^{\circ} \mathrm{C}$ without significant difference among the sources and all the samples did not comply with the WHO standard of temperature $<15^{\circ} \mathrm{C}$ [2] [17]. It has been established that outbreaks of waterborne diseases such as cholera are consistent with high temperatures [18]. Even if the climate in the West region is mainly cold climate, the average temperature ranged from $15^{\circ} \mathrm{C}$ to $22^{\circ} \mathrm{C}$ and sometimes reaches $30^{\circ} \mathrm{C}$ during the dry season [17] [18]. The study was carried out during the month of November characterized by high temperatures and rainfall [19] [20]; these factors could have influenced the water temperatures of water samples recorded at sampling sites of the study area. The recommended $\mathrm{pH}$ standard limits ranges from 6.5 to 8.5 [2] [17]. In this study, the $\mathrm{pH}$ value was found to be unacceptably low in $14(63.6 \%)$ samples. Globally, the $\mathrm{pH}$ of water samples ranged from 5.5 to 8.3 and a significant difference was found among sampling sites $(\mathrm{P}=0.04)$. The $\mathrm{pH}$ values of water samples fitted with the range 3 to 10.5 [21]; which could promote pathogenic micro-organism growth and were mostly higher among wells. This is consistent with findings of another study conducted in Bafoussam (West region), which found higher $\mathrm{pH}$ in groundwater than surfaces water such as stream [22]. More investigations need to be done to determine if the difference is could be due to seasons or soil compositions of the water sources. The turbidity of $20(90.9 \%)$ water samples was within the acceptable range of 1 - 5 NTU and this complies with WHO standards [2] [17]. The highest turbidity was recorded from river water sample. This finding is similar to a survey result in Ethiopia [23] which reported the highest turbidity record in untreated water such as river or sources.

Regarding the microbiological quality of water, the results showed that almost all types of water sources contained TC and higher load of TC was found among wells. This is consistent with the findings of study in Bafoussam, which reported high concentration of TC in groundwater (well water and stream) mostly during rainy season with TC concentration higher than $10 \mathrm{CFU} / \mathrm{mL}$ [22]. Our study was conducted in rainy season. The combined effect of elevated temperatures, $\mathrm{pH}$ and heavy rains could explain the high TC concentration observed in this period. Additional investigations are required to further assess this relation. It is also important to note that the water sources analyzed in this study were close to latrines. This might favor external contamination by runoff water. In 20 (90.9\%) water samples, TC counts were above the recommended levels $(<1 \mathrm{CFU} / 100 \mathrm{~mL})$ set by WHO [2] [17], including treated sources (chlorinated sources) indicating an insufficient or inadequate treatment of the sources. However, the TC concentration of untreated source water was found to be higher than treated water sources with no significant difference. The IMViC test clearly identified the presence of Enterobacter spp., Klebsiella spp., E. coli spp., Salmonella spp. and Shigella spp. in the water samples. Some of these organisms had already been highlighted by previous studies [22] [23] [24] [25]. In view of microbiological re- 
sults, almost all water sources were of poor quality and non-potable for human consumption. The presence of high pathogenic bacteria such as Klebsiella spp., Salmonella spp., Shigella spp. highlights the risk of severe waterborne diseases in the population, especially among under 5 children.

\section{Conclusion}

Most diseases affecting people, especially under 5 children are water-related diseases resulting from a lack of safe and whole water supply. Water is essential for human life, thus should be clean and safe. The field application MBS method as presumptive test in this study showed that this method is most adapted for limited resources settings as it is rapid, less expensive and does not require skilled personnel. Almost all water samples met WHO standards of physical appearance and turbidity. But this study revealed that water that appears clear may not necessarily be safe or potable as almost all were contaminated with very pathogenic agents. The temperature was found to be unacceptably high in all water samples and $\mathrm{pH}$ value was found to be unacceptably low in $2 / 3$ of samples, not meeting WHO standards. Minimal distance of water sources to the nearest latrine was not in line with WHO recommendations. This could explain the high load of coliforms bacteria in samples indicating environmental contamination from faecal due to proximity with latrines. We recommend integrating sanitary assessment in the design and implementation of water supply projects. Regular water purification using proper methods, water point's maintenances and supervisions, regular microbiological quality assessment of all domestic water sources intended for human consumption should be planned and carried out. Further research should be conducted to complete the microbiological profile of water sources in the West region of Cameroon.

\section{Conflicts of Interest}

The authors declare no conflicts of interest regarding the publication of this paper.

\section{References}

[1] Moyo, S., Wright, J., Ndamba, J. and Gundry, S (2004) Realizing the Maximum Health Benefits from Water Quality Improvements in the Home: A Case from Zaka District, Zimbabwe. Physics and Chemistry of the Earth, 29, 1295-1299. https://doi.org/10.1016/j.pce.2004.09.012

[2] World Health Organization (2011) Guidelines for Drinking-Water Quality. 4th Edition, World Health Organization, Geneva.

[3] World Health Organization (2019) National Systems to Support Drinking-Water, Sanitation, and Hygiene: Global Status Report 2019. UN-Water Global Analysis and Assessment of Sanitation and DRINKING-Water (GLAAS) 2019 Report. World Health Organization, Geneva.

[4] World Health Organization and United Nations Children's Fund (2017) Progress on Drinking Water, Sanitation, and Hygiene: 2017 Update and SDG Baselines. Geneva.

[5] Institut National de la Statistique (INS) et ICF International (2012) Enquête Démo- 
graphique et de Santé et à Indicateurs Multiples du Cameroun 2011. Institut National de la Statistique (INS) et ICF International, Calverton.

[6] Mabvouna, B.R., Sali, B.B.A., Nkamedjie, P.P., Sanou, S.M., Kemogne, J.B. and Colizzi, V. (2020) Microbiological Quality of Water Sources in the West Region of Cameroon: Quantitative Detection of Total Coliforms Using Micro Biological Survey Method. BMC Public Health, 20, Article No. 346. https://doi.org/10.1186/s12889-020-8443-0

[7] European Drinking Water Directive (1998) Europe Council Directive 98/83/EC on the Quality of Water Intended for Human Consumption. Official Journal L, 330, 0032-0054.

[8] United States Environmental Protection Agency (2018) Contaminant Candidate List (CCL) and Regulatory Determination. Types of Drinking Water Contaminants. U.S. Environmental Protection Agency, Office of Water (4303T), Washington DC. https://www.epa.gov/ccl/types-drinking-water-contaminants

[9] Nahar, A., Ahmed, M.M. and Chakraborty, A. (2011) A Quality Analysis of Dhaka WASA Drinking Water: Detection and Biochemical Characterization of the Isolates. Journal of Environmental Science and Natural Resources, 4, 41-49. https://doi.org/10.3329/jesnr.v4i2.10133

[10] Acharjee, M., Jahan, F., Rahman, F. and Noor, R (2013) Bacterial Proliferation in Municipal Water Supplied in Mirpur Locality of Dhaka City, Bangladesh. CLEANSoil, Air, Water, 42, 434-441. https://doi.org/10.1002/clen.201200618

[11] Matteo, G., Beatrice, N., Lorenza, M., Alyexandra, A., Laura, D.G. and Giovanni, A. (2018) Field Application of the Micro Biological Survey Method for the Assessment of the Microbiological Safety of Different Water Sources in Tanzania. Journal of Public Health in Africa, 9, Article No. 905. https://doi.org/10.4081/jphia.2018.905

[12] Colizzi, V., Mezzana, D., Ovseiko, P.V., Caiati, G., Colonnello, C., Declich, A., et al. (2019) Structural Transformation to Attain Responsible BIOSciences (STARBIOS2): Protocol for a Horizon 2020 Funded European Multicenter Project to Promote Responsible Research and Innovation. JMIR Research Protocols, 8, e11745. https://doi.org/10.2196/11745

[13] Bureau Central des Recensements et des Etudes de Population-Ministère de l'Economie, de la Planification et de l'Aménagement du Territoire Cameroun (2005) Recensement Général de la Population et de l'Habitat. http://nada.stat.cm/index.php

[14] Micro Biological Survey (2019) MBS-HACCP\&WATER Easy Test: The Lab in a Vial. https://www.emmebiesse.net/en/igiene-alimentare-haccp/

[15] Holt, J.H. (1994) Bergey's Manual of Determinative Bacteriology, 9th Edition, Lippincott Williams \& Wilkins, Philadelphia.

[16] Alfrad, E.B. (2007) Bensons Microbiological Applications. Mc Graw-Hill Book Company, New York.

[17] World Health Organization (1997) Guidelines for Drinking-Water Quality: Surveillance and Control of Community Supplies. Vol. 3. 2nd Edition, WHO, Geneva.

[18] Fernandez, M.A.L., Bauernfeind, A., Jiménezn, J.D., Gli, C.L., Omeiri, N.E. and Guibert, D.H. (2009) Influence of Temperature and Rainfall on the Evolution of Cholera Epidemics in Lusaka, Zambia, 2003-2006: Analysis of a Time Series. Transactions of the Royal Society of Tropical Medicine and Hygiene, 2,137-143. https://doi.org/10.1016/j.trstmh.2008.07.017

[19] Nkue Nouwezem, D.J. (2012) Variabilité pluviométrique et gestion des ressources en eau à l'Ouest du Cameroun. Université de Dschang, Cameroun.

[20] Institut National de la Statistique (2017) Cadre physique et climatologie, chapitre 1. 
Annuaire Statistique du Cameroun, 2017 Edition, INS, Yaoundé.

[21] Kunte, D.P., Yeole, T.Y., Chiplonkar, S.A. and Ranade, D.R. (1998) Inactivation of Salmonella typhi by High Levels of Volatile Fatty Acids during Anaerobic Digestion. Journal of Applied Microbiology, 84, 138-142.

https://doi.org/10.1046/j.1365-2672.1997.00335.x

[22] Mpakam, HG., Kamgang, K.B.V., Kouam, K.G.R., Tamo, T. and Georges, E.E. (2006) L'accès à l'eau potable et à l'assainissement dans les villes des pays en développement: Cas de Bafoussam (Cameroun). VertigO-la revue électronique en sciences de l'environnement.

[23] Gonfa, D., Fassil, A. and Mulissa, J (2019) Assessment of Bacteriological and Physicochemical Quality of Drinking Water from Source to Household Tap Connection in Nekemte, Oromia, Ethiopia. Journal of Environmental and Public Health, 2019, Article ID: 2129792. https://doi.org/10.1155/2019/2129792

[24] Tasnia, A., Mrityunjoy, A., Shohanur, R., Monirunnessa, M., Janifar, J., Saurab, K.M. and Rashed, N. (2013) Microbiological Study of Drinking Water: Qualitative and Quantitative Approach. Asian Journal of Microbiology, Biotechnology \& Environmental Sciences, 15, 23-458

[25] Deepesh, K., Shurutikirti, M., Molly, M., Anita, P. and Ashish, K.A (2013) Bacteriological Analysis of Drinking Water by MPN Method in a Tertiary Care Hospital and Adjoining Area Western Up, India. IOSR Journal of Environmental Science, Toxicology and Food Technology, 4, 17-22. 